\title{
Investigating Male and Female EFL Students' Learning Style at Muhammadiyah University of Makassar
}

\author{
Hijrah \\ hijrah1618fahmi@gmail.com \\ Haryanto \\ aharyanto_fbsunm@yahoo.co.id \\ Murni Mahmud \\ dwimurnye@yahoo.com \\ Universitas Negeri Makassar, Indonesia
}

\begin{abstract}
This study is intended to answer the main research questions related to the students' learning style preferences that used dominantly by male and female students at Muhammadiyah University of Makassar in 2017/2018 academic years. Their gender differences in communication affect the students' learning style. There were 20 students involved as the participants of the study which were selected by using convenient sampling. The data were collected by using three instruments: observation, diaries and questionnaire. Then, the data were analyzed by using mixed methods both qualitatively and quantitatively. Qualitative data were obtained from observations and diaries while quantitative data were obtained from questionnaires. The procedures of data analysis consisted of data reduction, data display, and drawing conclusion or verification. The result of this study shows that the learning style that used dominantly by female students is kinesthetic learning style. Moreover, the data also showed that male students tend to use the auditory learning style. Whereas, in terms of individual and group learning style preference, there were no significant differences between male and female in working as a group and individual. In addition, there is an effect of gender difference in term of learning style because of the notions of male and female's communication. The male students' preferred auditory learning style because male students tended to enjoy and more active to learn by hearing music and short video as learning media. On the other hand, female students preferred kinesthetic learning style because they learn best by being involved physically in the classroom, such as learning by doing and learning by using games. These styles of learning are affected by the notions of gender differences in communication.
\end{abstract}

Keywords: Learning Style, Visual, Tactile, Auditory, Kinesthetic

\section{INTRODUCTION}

Learning style is one of the predominant factors which affect the students' success in the learning process. Shabani (2012) stated that a student's learning style preference deals with his/her way to respond to the stimulus in a learning context, 
and the student's specific way of acquiring the knowledge. Thus, teachers and educators should not ignore the identification of students learning styles. Therefore, understanding the students learning or styles are important in the learning process. The learning styles component as a decisive input might highly help teachers overcome many pedagogical problems.

Felder and Brent (2004) mention that an understanding of the students' learning styles can help educators to adjust their teaching styles in order to address the students' need. Furthermore, Kaplan and Kies (1993) have also stressed the utility of learning style awareness on the part of teachers and learners.

For the case of English language learning, studies conducted a study gender influence on students' learning style preferences have reported mixed findings (Nadia et al., as cited in Shuib and Azizan, (2015).These findings revealed that gender difference exists in learning style preferences among the students. Afzal et.al (2015), on the other hand, reported that gender did not seem to influence the students learning style preferences among students. The inconsistency of findings on gender difference in students' LSP suggests that more studies are needed in this area of research.

Regarding to explanation above, this study was intended to investigate the learning style used dominantly by male and female students at Muhammadiyah University of Makassar, and gender differences in communication affect the students' learning style.

\section{LITERATURE OF REVIEW}

\section{Related Studies}

Studies of learning style have been carried out by some researchers with varying degrees of success and context. Mahmud (2010) explored the impact of gender differences in English language teaching. The samples involved were from 2008 from 20 males and 20 females' English students of State University of Makassar. She found that male students were tended to be passive in the class and being shy to speak with their cross-gender. Vice verse, female students tended to work with the same sex. She concluded that male and female are different in their learning style. These different styles were affected by notions of women's language.

Liu and Shi (2015) explored the learning style preferences of 1701 Chinese University learners in terms of general patterns, gender, and discipline differences. This study revealed that Chinese University learners tended to be active, sensing, verbal, and global learners. Moreover, the male and female Chinese University students were significantly different on their Visual-Verbal, Sequential-Global, and Active-Reflective. They concluded that students' gender and their discipline were significantly impacting their learning style preferences.

Ramezani, et al. (2015) conducted a study exploring the learning style preferences of 40 Iranian students which consist of 20 males and females students at Mare fat high school in Kuala Lumpur. The results showed that the learning style preferences of Iranian students were different according to their gender. Female 
students preferred auditory learning as their major learning style, while male students preferred kinesthetic more. Moreover, the findings revealed that kinesthetic learning was the least preferred learning style of the most female students, whereas the least preferred learning style of male students was tactile learning.

Jamiah, Mahmud and Muhayyang (2015) investigated the students' language learning strategies by collecting data from 15 male students and 15 female students of the second grade at SMA Negeri 11 Makassar. Mostly, females used social strategy because they were more emphatic, social thinking and like cooperating with their peers while the males preferred to the compensation strategy because their characteristics were more confident, fun, logical, active in expressing their opinion. They concluded that gender differences affect in choosing language learning strategies.

\section{Learning Style}

According to Brown (2000), how learners perceive, interact with, and respond to the learning environment are the indicators of learning style. Moreover, Ellis (2001) stated that learning style is the consistent pattern of behavior and performance by which an individual approaches educational experiences. Determining students' learning style is important to facilitate the students in identifying the most effective way for them to gain a deeper understanding on certain subjects and make the learning process easier for them. In addition, Husain (2011) stated that learning styles describe the students in terms of educational conditions under they are most likely to learn, or preference in absorbing and retaining new information during the teaching and learning process..

\section{METHOD}

This research employed mixed methods, both quantitative and qualitative design. Mixed methods research is a methodology for conducting research that involves collecting, analyzing and integrating quantitative and qualitative research. The participants in this research were the second-semester students of English Language Education Department, Muhammadiyah University of Makassar in 2016-2017 academic years. In selecting the participants, the researcher employed convenience sampling. Convenience sampling is a nonprobability sampling technique where subjects are selected because of their convenient accessibility and proximity to the researcher. The main instrument is the researcher while the supporting instrument is the observation sheet, diary and questionnaire. In this study, the Perceptual Learning Style Preference Questionnaire (PLSPQ) developed by Reid (1984) was used to measure the students' preferred learning styles. The researcher applied data analysis technique from Miles, Huberman \&Saldana (2014) which comprises of data collection, data condensation, data display, and conclusions: drawing/verifying. 


\section{RESULT AND DISCUSSIONS}

This part provides the findings and discussions of the students' questionnaire and diaries answered by the respondents regarding their learning styles in learning English as affected by gender differences.

\section{The Learning Style Used Dominantly By Male and Female Students at Muhammadiyah University of Makassar}

The following findings were taken out from the deep analysis in the form of observation and diaries for considering the students' preferences that related to the learning style (visual, tactile, auditory, kinesthetic, group, and individual).

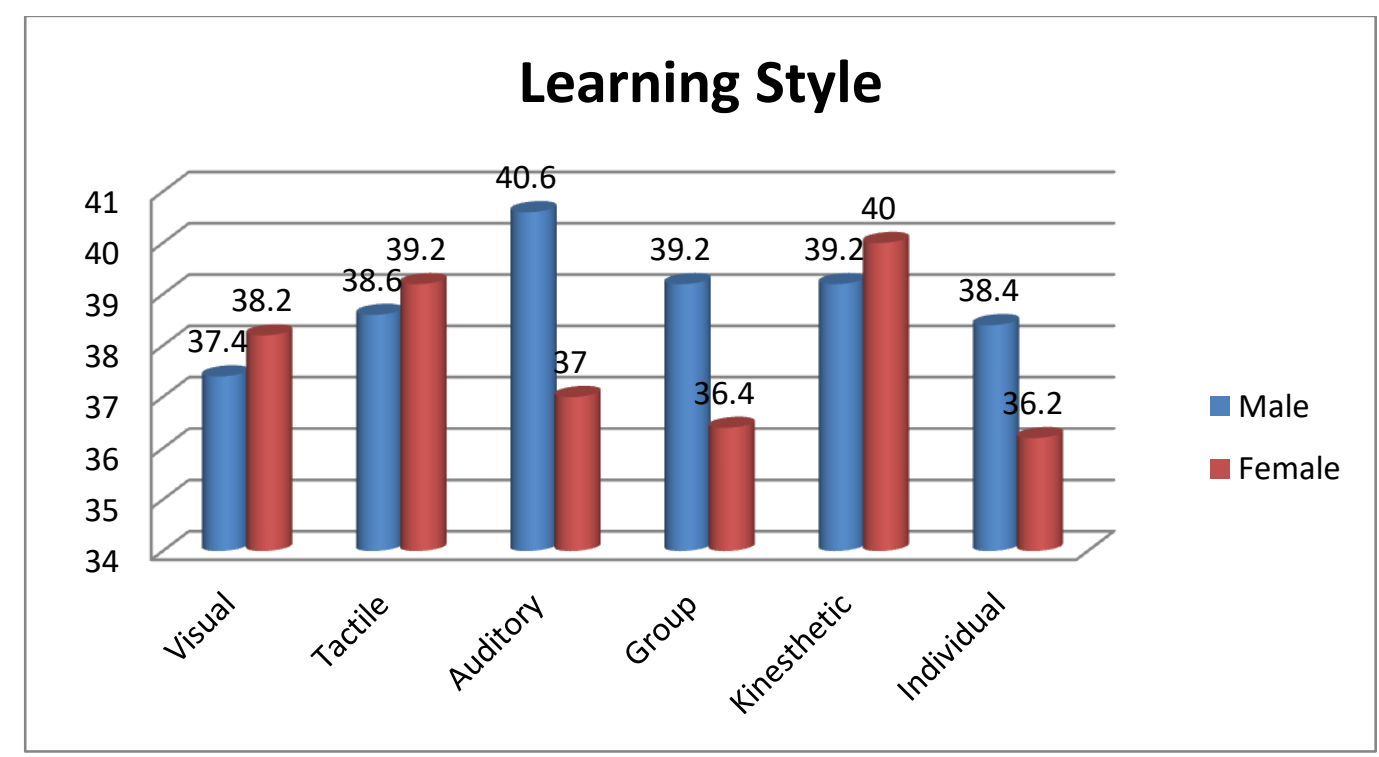

Figure 7. Learning Style Used Dominantly by Male and Female Students

The data about major learning style preferences indicate how frequently the students use learning style in learning English. Based on figure 4.7, it shows that the descriptive statistics analysis for the mean score of the data obtained from the students' questionnaire. It reveals that the male students used dominantly auditory major learning style preference while female students used dominantly kinesthetic major learning style preference which the mean score 40.6 and 40.

Most of the participants both male and female need visual stimulus to help them understand or remember the information in the learning process. Additionally, most of the diaries wrote by the participants explain that they learn better while their teacher used visual aids such as a picture, film, map or simply powerpoint.

"I still remember my lessons two months ago in the reading class because my lecturer used a sequence of pictures in our learning process. It was really help me a lot and I hope it happen in all subjects...." 
(Female 1, diaries, on August $7^{\text {th }}, 2017$ )

"I like watch movie that is why when the lecturer present the subject by using short movie, I am so interested and can understand the lesson easily."

(Male 5, diaries, on August $7^{\text {th }}, 2017$ )

"Pictures exaggerate my mind to think creatively...."

(Male 8, on August $7^{\text {th }}, 2017$ )

Tactile learning style is learned more effectively through touch (hands-on). In other words the students learn better while they use their sense throughout the lesson. Based on observation, the researcher found out that the project which is the lecturer assigned to the participants affect students' way in facing their class. They were more eager to participate and give positive feedback to the class.

Additionally, the participants admitted in their diaries that classroom project increased their mood to absorb the lesson and as a result they understand well what the lecturer tried to deliver in the class.

"Project class is my mood booster. It increases my interest to learn more and make me understand the lesson well. I am happy to have a class that the lecturer assigned us a project that we should do. Pokoknya really reall yreally interesting deh. hehehehe...."

(Female 1, diaries, on August $7^{\text {th }}, 2017$ )

“...about tugasnya (sorry I don't know in English) is very good. Cuttingcutting and stick-stick in the paper. So fun and I enjoy it with my friends."

(Female 1, diaries, on August $7^{\text {th }}, 2017$ )

"I'm so enjoying the class today because my Dosen give me project and tunjuk me as leader. So, I can choose my anggota then I choose my close friends..."

(Male 2, diaries, on August $7^{\text {th }}, 2017$ )

"It is quite good and fun while my Lecturer gave me project because I can work with my friends in the class. Trying to do and act based on the instruction provided by our lecturer; I feel happy and use all my senses, explore and etc."

(Male 5, diaries, on August $7^{\text {th }}, 2017$ )

Students who had auditory learning style were able to more learn effectively through the ear (hearing). Besides, auditory students are comfortable without visual input and thus enjoy and profit from unembellished lectures, conversations, and oral directions. They are excited by classroom interactions in role-plays and analogous activities. Related to this research, the observation held by the researcher in the classroom indicates that some female students enjoying the instrument music background along with the short video played by the lecturer in her class. The opposite happened in another gender which is mostly Male students 
looked excited while the music background in the presentation played. In the middle of her slide presentation in the classroom, the lecturer played a short video that showing short conversation related to her subject with instrument music background.

"It is easy listening and because I love music so I enjoy it. Why? Music can hibur me. I always listen to the music if I'm sad and directly I happy. Tadi my lecturer played instrument music I really really like it."

(Female 1, diaries, on August $7^{\text {th }}$, 2017)

"My friends and I like the video because there is music there and can entertain us. Also it is example of saying rejection to offer. I can practice well because there is example in the video."

(Female 3, diaries, on August $7^{\text {th }}$, 2017)

"Related to music: I like music because make me so so happy and I like music because I always sing but only in the bathroom. If I study at home I always putar music terutama music anak muda."

(Male 10, diaries, on August $7^{\text {th }}$, 2017)

"Music in the video so relaxing. I like it, good for study. Music make me not stress.

(Male 5, diaries, on August $7^{\text {th }}, 2017$ )

As mentioned above, male students differently with female student where mostly male students look happy when the lecturer played the video that contained instrument music as background but only some female students look happy instead they showed pale face and sometimes look tired.

"Actually I like music but in the lesson barusan make me remember my bad past with someone so I don't like it."

(Female 2, diaries, on August $7^{\text {th }}, 2017$ )

"The music make me very sleepy and want to sleep so I cannot focus. Also I cannot hear what the people say in that video"

(Female 8, diaries, on August $7^{\text {th }}, 2017$ )

Kinesthetic students learn more effectively through concrete complete body experience (whole-body movement). Kinesthetic and tactile students like lots of movement and enjoy working with tangible objects, collages, and flashcards. Sitting at a desk for long is not for them; they prefer to have frequent breaks and move around the room. Kinesthetic learners also learn by manipulating objects. They need to involve their whole body in learning. The analysis based on observation data revealed that with around 2 minutes ice-breaker activities lead by the lecturer that involved some body movements allowed the students to avoid awkward feeling in making conversation each other between the students. This is made them easy to start their project game as a practice in their class. 
"The games and activity that my teacher delivered in the class just now is helping me so I'm not shy to talk with my friends meskipun I buat banyak mistakes in speaking English."

(Female 1, diaries, on August $7^{\text {th }}, 2017$ )

"I don't like to sit down many times so I very enjoy to stand up and talking with my friends. I can free to talk. I like if I standing up because give me freedom to express anything I want."

(Female 3, diaries, on August $7^{\text {th }}, 2017$ )

"It is so fun to make keributan and talking with loud voice. Walkingwalking around and learn how to reject and offer langsung praktek. I like this."

(Male 2, diaries, on August $7^{\text {th }}, 2017$ )

"Learning by doing is good for me and I like it. I can learn a lot by doing it directly. Because if I not do it sometimes I don't understand it. That is why I like it."

(Male 4, diaries, on August $7^{\text {th }}, 2017$ )

Students who had major group learning style preference learn easily when they study with at least one other student, and they will be more successful in completing work well when they work with others. They value group interaction and class work with other students, and they remember information better when they work with two or three classmates. The stimulation they receive from group work helps them to learn and understand new information. Based on this research result of students' diary, it reveals that most of them preferred work in a group because they can share work with each other and help each other in completing the tasks.

"About work in group or individual, I like group because we can bagibagi tugas but kadang-kadang I like individual."

(Female 5, diaries, on August $7^{\text {th }}, 2017$ )

"I preferred to in group not individu because it can menutupi kekurangan masing-masing."

(Male 3, diaries, on August $7^{\text {th }}, 2017$ )

"I chose to work in group because we can share each other."

(Female 9, diaries, on August $7^{\text {th }}, 2017$ )

"...about group or individual I preferred to work in group because can make me happy and very terbentuk."

(Male 4, diaries, on August $7^{\text {th }}, 2017$ )

"So, it preferred to work in group because I can work with my friend."

(Male 2, diaries, on August $7^{\text {th }}$, 2017)

Students who had major individual learning style preference learn best when they work alone. They think well when they study alone, and they remember 
information that they learn by themselves. They understand new material best when they learn it alone, and they make better progress in learning when they work by themselves. The analysis based on the students' diary reveals that most of the students preferred to study individually because they feel comfort and more focus when they learn alone without disturbing from their classmates. As mentioned in the following extract below.

"About work in group or individual, I chose individual because I more focus if alone."

(Female 7, diaries, on August $7^{\text {th }}, 2017$ )

"And I chose work individual because I can focus tanpa diganggu siapa pun."

(Male 1, diaries, on August $7^{\text {th }}, 2017$ )

"I preferred work in individual because I don't like keributan."

(Female 8, diaries, on August $7^{\text {th }}, 2017$ )

"I chose individual because I merasa can not mengerjakan tugas is too many people."

(Male 7, diaries, on August $7^{\text {th }}, 2017$ )

"Honestly I preferred to work individual because I can focus and not disturbed by others."

(Male 8, diaries, on August $7^{\text {th }}, 2017$ )

The following results were taken out from the deep analysis in the form of questionnaire regarding to the students' learning style (group and individual) in terms of gender differences. The following pie chart is the result of questionnaire based on the students' preferences in Group and individual learning style.

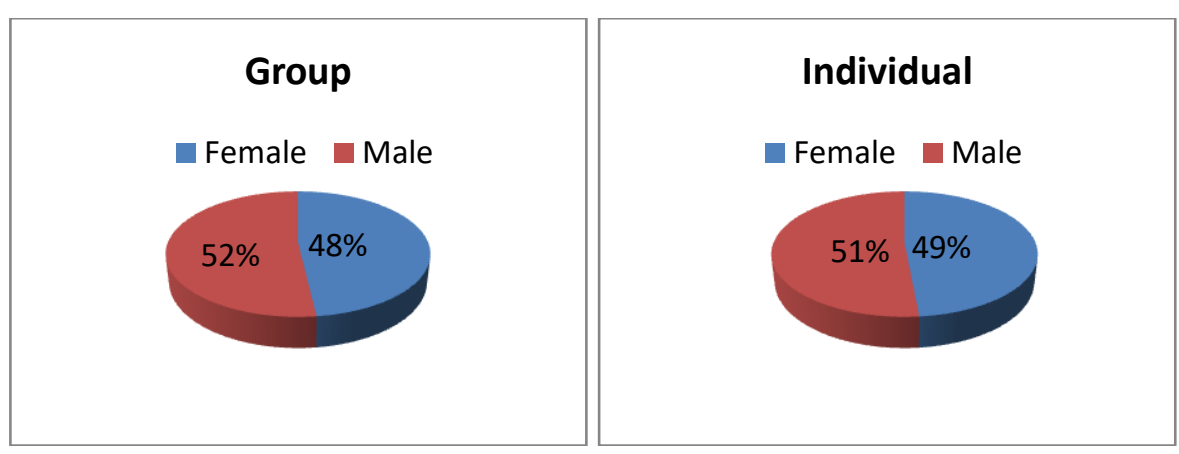

Figure 8 Learning Style Preferences in Group and Individual

Figure 8 reveals that there were no significant differences between male and female in working as a group and individual. The data showed that $52 \%$ of Male preferred to work in a group and $51 \%$ of them enjoy to work by themselves. This 
also happened in another gender, $48 \%$ of Female tends to work in a group and $49 \%$ of them chose to work individually.

\section{Gender Differences in Communication Affect the Students' Learning Style}

This part describes the discussion of the observation results and students' diaries regarding to their learning styles in learning English as affected by gender differences based on their perceptions. The detail descriptions are presented as follows.

\section{Students' Feeling and Reasons to Speak English with Different Sex}

Based on the observation and students' diaries regarding to the students' feeling to speak English and in class, there were differences between male and female students' reasons to speak English, especially when they speak English with the different sex. The female students more felt reluctant to speak English with a different sex. They feel more enjoyable to speak English with the same single-sex. Meanwhile, some male students felt reluctant to speak English with the different sex, i.e. with female students. They dominantly stated that they could and be enjoyable to communicate and speak using English well whether with both sex, i.e., male and female students. Their reasons are presented in the following table 1 .

Table 1. Students' Feelings and Reasons to Speak English with Different Sex

Males' Feeling \& Reasons

1. Ashamed and afraid to make mistakes when speak English with the male students.

2. Not being free and feeling shy to speak English with males.

\section{Females' Feeling \& Reasons}

1. Feeling shy and not confident to speak English if females are smarter than them.

2. Males like to show up and dominate the discussion.

\section{Students' Preferences to be Active or Silent in English Class}

In English class, female and male students also showed different preferences to be active or silent involved themselves in the learning activities. Based on the observation and students' diaries, it revealed that male students were more active in the class rather than female students. Female students tended to be more silent. The reasons for being active or silent in English class as mentioned by female and male students are presented in Table 2 as follows.

Table 4.2 Students' Reasons for Being Active or Silent in English Class 


\begin{tabular}{|c|c|c|}
\hline Active & $\begin{array}{l}\text { - try to practice } \\
\text { - to know more } \\
\text { - to show up } \\
\end{array}$ & $\begin{array}{l}\text { - depending on situation } \\
\text { - encouraging to involve in the } \\
\text { class }\end{array}$ \\
\hline Silent & $\begin{array}{l}\text { - not interested with the material } \\
\text { and topic } \\
\text { - having less vocabulary } \\
\text { - having not good English and } \\
\text { pronunciation to speak English } \\
\text { - feeling moody }\end{array}$ & $\begin{array}{l}\text { - } \text { ashamed and afraid } \\
\text { - feeling nervous and not } \\
\text { confident to speak because } \\
\text { afraid to make mistakes } \\
\text { - feeling doubt to express their } \\
\text { opinion } \\
\text { - not understand the material } \\
\text { and the explanation } \\
\text { - feeling moody } \\
\text { - not interested to the material }\end{array}$ \\
\hline
\end{tabular}

Jamiah, Mahmud and Muhayyang (2015)

\section{Students' Preferences in Working with Groups and Individual}

Female and male students also showed different preferences in terms of working with group and individual in the English class. The reasons for working in group and individual as mentioned by female and male students are presented in Table 3. More male students preferred working in group meanwhile most female students preferred working in individual pattern. Male students' reasons tend to work in a group, such as they more feel cooperative with others, feel easier to understand the materials and tasks because they can work with friends and help each other in completing the tasks, they can share ideas with their classmates or friends, and they feel happy to work with their friends and can motivate each other to complete the group tasks.

On the other hand, female students prefer working in an individual pattern. Their reasons to prefer working in individual are such as they are easier to manage things, they feel free and comfortable when do the tasks alone, they can more focus if they do the tasks alone, and they don't like noisy and crowded.

Table 3 Students' Reasons for Working in Group and Individual

\begin{tabular}{|c|c|c|}
\hline & Male Students & Female Students \\
\hline Group & $\begin{array}{l}\text { - More cooperative } \\
\text { - Easier to understand } \\
\text { - Can work with friends or } \\
\text { classmates } \\
\text { - Help each other in completing the } \\
\text { tasks } \\
\text { - Feel happy and motivate each } \\
\text { other to complete the group tasks } \\
\text { - Can share ideas with friends and } \\
\text { classmates }\end{array}$ & $\begin{array}{l}\text { - More open minded } \\
\text { - More responsible } \\
\text { - Can share ideas and tasks each } \\
\text { other }\end{array}$ \\
\hline Individual & $\begin{array}{l}\text { - More focus and not disturb by } \\
\text { others }\end{array}$ & $\begin{array}{l}\text { - More easy to manage things } \\
\text { - More comfortable }\end{array}$ \\
\hline
\end{tabular}


- Cannot do the tasks because there are many people
- Feel free

- More focus if they do it alone

- Don't like noisy and crowded

Lead by the data analysis, the male students preferred auditory learning style because they tend to give feedback by speaking form rather than writing form, they chose to read the text loudly or listened to their friends read it for them, and also they were easy to get distracted by noises around them. In another gender, female students preferred kinesthetic learning style because they feel comfortable for being an example and role model in the class and also giving feedback by asking for clarification rather than asking for a correction.

\section{CONCLUSIONS}

Based on the result findings, the conclusions of this study are: 1) the learning style used dominantly by female students is kinesthetic learning style, which shown by quantitative data score of female kinesthetic learning style is 40 while the male is 39.2. Moreover, the data also showed that the male students tend to use auditory learning style with shown by score 40.6 for male while the female is 37 . Whereas, in terms of individual and group learning style preference, there were no significant differences between male and female in working as a group and individual. The data showed that $52 \%$ of Male preferred to work in a group and $51 \%$ of them enjoy to work by themselves. This also happened in another gender, $48 \%$ of Female tends to work in a group and $49 \%$ of them chose to work individually; 2) there is an effect of gender difference in term of learning style because of the notions of male and female's communication. The male students' preferred auditory learning style because male students tended to give feedback by speaking form rather than writing form. They chose to read the text loudly or listened to their friends read it for them, and also they were easy to get distracted by noises around them. While, female students preferred kinesthetic learning style because they feel comfortable for being an example and role model in the class and also giving feedback by asking for clarification rather than asking for a correction. These styles of learning were influenced by the notions of gender differences in communication.

It is suggested, therefore, to know the students' learning style so that they can fulfill the need of students, need of education, and need of government, to find more related to students' learning style in some different University as the representatives who cover South-Sulawesi. In addition, it is suggested to other researchers to find out how to deal with the students who had those learning styles. 


\section{REFERENCES}

Brown, H.D. (2000). Principles of Language Learning and Teaching. New York: Pearson Education.

Ellis, A. K. (2001). Research on Educational Innovations, $3^{\text {rd }}$ edition. New York: Eye on Education, Inc.

Felder, R. M., \& Brent, M. (2004).Understanding students' differences.Journal of Engineering Education, 94(1), 57-72.

Husain, D. (2011).Fostering Autonomous Learning Inside and Outside the Classroom in Language Learning. Makassar: Badan Penerbit UNM.

Jamiah, Mahmud, Muhayyang. (2015). Do male and Female Students Learn Differently. ELT Worldwide2(2), 110-125.

Kaplan, E. G., \& Kies, D. E. (1993). Together: Teaching styles and learning styles in improving college instruction. College Student Journal, 24(4), 509-513.

Liu, M. and Shi, J. (2015). Chinese University Students' Learning Styles: Gender and Discipline Differences. Institute for Learning Styles Journal, Vol. 1, p. $1-16$.

Mahmud, M. (2010).Language and Gender in English Language Teaching.TEFLIN Journal, Vol. 21, p.172-185.

Miles, M. B., Huberman, A. M. and Saldana, J. (2014). Qualitative Data Analysis: A Methods Sourcebook, $3^{\text {rd }}$ Edition. California: SAGE Publication, Inc.

Ramezani, A. E., Dehgahi, M. and Hashemi, H. (2015).An Exploratory Study of the Language-Learning Style Preferences of Iranian EFL High School Students.Journal of Advances in Language and Literary Studies, Vol. 6, No. 2, p. 150-159.

Reid, J. (1984). Perceptual Learning Styles Preference Questionnaire.

Shabani, M. B. (2012). Different Learning Style Preferences of Male and Female Iranian Non-Academic EFL Learners.Journal of English Language Teaching, Vol. 5, No. 9, p. 127-137.

Shuib, M. and Azizan, S. N. (2015). Learning Style Preferences among Male and Female ESL Students in Universiti-Sains Malaysia. Journal of Educators Online-JEO, Vol. 13, Number 2, p 103-141. 